\title{
Off the Beaten Track: A reflection on intention and unpredictability in arts education research
}

\author{
Por el Camino Menos Transitado: Reflexiones \\ sobre la intención y la dificultad de predecir en \\ la investigación sobre educación artística
}

\section{Hors des sentiers battus: Une réflexion sur l'intention et l'imprévisibilité dans la recherche en éducation artistique}

\author{
Kathleen Gallagher \\ University of Toronto, Canada
}

\begin{abstract}
The coherence of a 'research program' is often betrayed by the unanticipated turns and detours in arts research. The following article reflects upon the place of the unexpected in arts research, the alternative ways in which knowledge or 'findings' are often constructed, and the complexity of calibrating or measuring arts research for broader publics. UNESCO's road map is seen here as a site for further deliberation, a point in time and space that should engage arts communities in rousing dialogue - locally and globally - about the convergences and divergences of our practices and research paradigms.
\end{abstract}

Key words: arts education; research paradigms; drama education; creativity; methodological innovation.

RESUMEN

En la investigación artística, la coherencia de un "programa de investigación" suele ser traicionada por las vueltas y desvíos imprevistos del camino. El siguiente artículo es una reflexión acerca del lugar de lo inesperado en la investigación artística, las maneras alternativas en las que el conocimiento o los "hallazgos" a menudo se construyen y la complejidad que implica calibrar o medir la investigación en artes para públicos más amplios. Para ello, la hoja de ruta de la UNESCO es considerada como la instancia para una deliberación más extendida, un punto en el tiempo y en el espacio que debería involucrar a las comunidades artísticas en un apasionado diálogo, a nivel local y global, acerca de las convergencias y divergencias de nuestras prácticas y nuestros paradigmas en investigación. 
Descriptores: educación artística; paradigmas de la investigación; educación en drama; creatividad; innovación metodológica.

\section{RÉSUMÉ}

La cohérence d'un " programme de recherche » est souvent trompée par les tournants et les détours imprévus dans la recherche artistique, les façons différentes dans lesquelles les connaissances ou les résultats sont souvent formulés et dans la complexité de l'étalonnage ou de la mesure de la recherche artistique pour des publics plus larges. La carte de route de l'UNESCO est perçue ici comme un terrain pour poursuivre la réflexion, comme un point dans le temps et l'espace qui devrait engager les communautés artistiques dans un dialogue passionné-au niveau local comme au niveau global — au sujet des convergences et des divergences de nos pratiques et de nos paradigmes de recherche

Mots clés : I'éducation aux arts ; un paradigme de recherche ; la pédagogie des arts dramatiques ; la créativité ; I'innovation en méthodologie.

\section{A Road Map of Sorts}

$\mathrm{A}$ CADEMICS LIKE TO TALK about A 'research program' as though our research work is always a coherent proposition, a linear program with obvious beginnings and predictable outcomes. I would venture a guess that many arts researchers began their careers as teachers of the arts, or artists, or both. And these auspicious beginnings are likely what drew them to research in the arts. So when I think now about "navigating the UNESCO road map for arts education" as the special issue of this journal promises to do, I look back on my last 20 years as an arts teacher and researcher and realize that in this eclectic mix of experiences, I have been involved in a process of imagining art as an entry point to a life examined. The arts have been the navigational tools that have, for me, raised questions of great importance in the field of education broadly speaking.

A 'road map' in research is a very useful concept. Roxana $\mathrm{Ng}$ and Kiran Mirchandani (2008) have recently used the concept of "mapping" as a conceptual and methodological tool to link lived experiences with institutional processes. This, too, is a useful idea for arts education research. How do we understand the relationship between arts educators and the institutions in which they work? These researchers use mapping as a point of entry into individual experience, but do so in order to keep an analytical focus on the interface between individual lives and institutional relations.

As long as our road map in arts education shows the contours of the landscape, the twists and turns and bends in the road, I can live with the metaphor. But if we are looking for the GPS system for arts education, the disembodied voice who will direct us with great accuracy from point A to point B, then I will betray my life in the arts. And so, the road map as metaphor for me must include the sight-seeing, the bathroom breaks, the picnic on the side of the road, and the 'unanticipated' in all respects.

In this paper, I will navigate my way through a 'program' of research in the arts. In it, the reader will find a map of sorts, one that I hope clearly points to the ways in which the arts are harnessed to matters of social, academic, and artistic significance. 
For me, it begins with a fruitful rethinking of the notion of "objectives" in arts research, wherein the question becomes: What do we find when were looking for something else? I would like to trouble the idea of objectives in arts research in order to ask questions of the methods we deploy and the ways in which the unpredictable takes hold of our research projects.

\section{Where might research take us?}

Over the course of my research career, I have worked on several different kinds of arts studies. If the UNESCO Road Map was drawn up in order, in part, to "advocate the importance and essential role of arts education" (see http://portal.unesco. org/culture/en/ev.php-URL_ID=39546\&URL_DO=DO_TOPIC\&URL_ SECTION=201.html) then the following 'map' of my years in research is the best navigational tool I have to speak to a basic concept in the initial UNESCO Road Map. I am speaking here of the goal to: "Uphold the Human Right to Education and Cultural Participation" (see http://portal.unesco.org/culture/en/ files/40000/12581058115Road_Map_for_Arts_Education.pdf/Road\%2BMap $\% 2 \mathrm{Bfor} \% 2 \mathrm{BArts} \% 2 \mathrm{BEducation}$.pdf). That an organization called The United Nations Educational, Scientific, and Cultural Organization led the charge on this ambitious project is no small indication of the reach of arts education, its cultural, educational, and scientific worth.

The studies I have spent my time with over these last 20 years can be loosely described as:

i) a teacher-researcher study of secondary school drama and adolescent girls;

ii) an action research study of transforming the teaching of social studies through drama;

iii) an ethnographic study of secondary drama classrooms in New York and Toronto;

iv) a mixed methods study of a touring play to elementary schools across the province of Ontario in Canada;

v) a life history study of drama and pedagogy in an urban school; and

vi) a multi-site hypermedia ethnographic study of drama learning in Toronto, Taipei, New York City, and Lucknow, India.

The point of this paper is not to share the 'findings' from these studies, interesting though they are, but I would like instead to use them as illustrations of how research sets us on a course, much like a good road map should. And in my own case, this map fundamentally asked how performance becomes a site of invention, which breaks open the purposes of and audiences for educational research in the arts. One small but not insignificant point that might be gleaned from this range of studies is how knowledge creation in arts education straddles the worlds of intention and unpredictability. And at the centre of these studies lies a methodological orientation I have recently come to articulate as a collaborative "problem-posing ethnography" (Gallagher, 2007). I came to this methodological discovery through thinking seriously about James Baldwin's 
claim that "the purpose of art is to lay bare the questions, which have been hidden by the answers" (in Lerman \& Borstel, 2003, p.8).

Surely if this is the purpose of art, then the purpose of research in the arts is to leave oneself open to the questions that are discovered in the course of asking other questions we think we are there to learn about. Lest this sound like an academic game of the never-ending question and the familiar retreat from answers, let me be clear that answers are not always the most important things about asking questions. Sometimes asking questions, the very act of asking them, puts assumptions on the table, sets up a dialectical possibility, and generates much needed dialogue and refinement of thinking. It might also open us up to answers that are looking for the right questions to be asked of them. It strikes me that art, as a product or a learning tool or an experience or a subject of research, almost always draws us towards questions of choice and intentionality as well as, paradoxically, questions of improvisation and imagination.

Here are, in brief, some examples of my learning what I was not there to learn or, learning from the unexpected. In the course of these studies, while I was researching theatre-making and theatre teaching in school contexts, I learned:

i) how much the social identities of young people matter in works of art and relationships of art-making;

ii) that being engaged in learning does not make you perform better on a test if a test disrespects the process of how the learning happened;

iii) that post 9-11 theatre-making in large North American city classrooms was part of both a complicity with, and a resistance to, popular cultural notions of urban youth;

iv) that sometimes the very best a touring theatre play can do in a school is alter forms of dialogue and therefore social relations between teachers and students;

v) that a teacher's idea about the community she works in significantly changes the kind of art-making she engages students in;

And finally, in my current study, I have already learned, two years in, when I was not looking,

vi) that performance is intimately tied to feelings of melancholia and disappointment in arts teachers. ${ }^{1}$

All when I was not looking, I learned these things.

So I pay attention to the unintentional in research because like art-making, nothing is insignificant even it if is bad, and it almost always clarifies something or offers a new way of seeing an old problem. These unintentional discoveries may even make central the real impact or effect of the arts that sometimes gets relegated to the margins. And by 'real' here, I mean nothing less than: Art as an entry to a life examined. ${ }^{2}$

\section{The Scientific Method}

Since antiquity, there has been what we might call an artificial bifurcation of art and science. One of the things we have inherited from the 'Scientific Method' is a belief in 
the relationship between analytical distance and truth. We live in a political, cultural, and educational climate that clearly privileges the 'scientific,' presumed to be the 'objective' and the 'distanced.' But in the arts, we understand that research might well be conceived as a series of moments, performances, creative encounters, and temporal relationships that can never be repeated, can seldom be generalized, are up close and personal, and NOT a series of value-free and distanced observations. ${ }^{3}$

In Irish playwright Brian Friel's (1999) view:

The arts grow and wither and expand and contract erratically and sporadically. Like beachcombers or Irish tinkers they live precariously, existing from idea to idea, from theory to theory, from experiment to experiment. They do owe something to the tradition in which they grow; and they bear some relationship to current economic and political trends. But they are what they are at any given time and in any given place because of the condition and climate of thought that prevail at that time and in that place. And if the condition and climate are not right, the arts lift their tents and drift off to a new place.

Flux is their only constant; the crossroads their only home; impermanence their only yardstick. Once they realize that they have been so long in one site that they have come to be looked on as a distinct movement, that city hall is thinking of extending the city boundaries so that they can be absorbed into a comfortable community, they take fright, attack the movement - the apparent permanence - that they themselves have created, reject the offer of hospitality, and move to a new location. This is the only pattern of their existence: the persistence of the search; the discovery of a new concept; the analysis, exploration, exposition of that concept; the preaching of that gospel to reluctant ears; and then, when the first converts are made, the inevitable disillusion and dissatisfaction because the theory is already out of date or was simply a false dawn. And then the moving on; the continuing of the search; the flux. Impermanence is the only constant (p. 16).

The research encounter in the arts is an uncertain and variable thing. The more we can tie this power of the ephemeral and the fleeting to our 'road maps' in teaching and research, the closer to 'home' we will be. But this is, of course, an uneasy fit with the Oxford English Dictionary's definition of research: Systematic investigation into and study of materials and sources, in order to establish facts and reach new conclusions. I am not sure how many facts I have established over the last 20 years, but what this definition leaves out is as important as what it says, the questions it begs: Do we create new knowledge: for its own sake?; in context?; for a particular context?; for social reform?; to advance an art form, or aesthetic understanding, or some combination of the above? 


\section{Driven by Creativity (but how do we measure it?)}

The UNESCO Road Map usefully argues that we make art for all of these reasons and we therefore need specialist and generalist teachers to work in all of these interesting ways. I could not agree more. It also highlights another relatively uncontested view in arts research circles:

The assumption is that Arts Education is one of the best media for nurturing creativity (when the methods of teaching and learning support it), but the mechanisms for this are not well documented and the argument is therefore not well received by policy makers. Further research into this area is therefore needed (p. 12 UNESCO Road Map).

If we agree that creativity can be nurtured by the arts, then it must be creativity in all its forms. And that means a proliferation of research methodologies, not a narrowing of our ways of seeing, critiquing, and communicating. We cannot simply take uncritically the pervasive discourse of the 'creative economy' or the 'creative class.' Our road map must also emphatically put forward other ideas, politically and socially engaged ideas, about creativity. Then, and only then, can we claim that an education in the arts is one of the best media for nurturing creativity.

The causes, the document goes on to outline, for our faltering influence in policy realms, can be explained by the fact that "in many countries this evidence is scarce, anecdotal and difficult to access" (p.12). The road map then recommends the circulation of 'best practice' case studies. But what I might propose as a more promising response than the call for 'best-practice' research, a discourse in evidence throughout the document, is for arts researchers and educators, generally, to develop an inquirybased approach to teaching and learning in the arts. Rather than circulating best practice' research that is context-specific, I would suggest that creating an international culture of inquiry in the arts might better serve, in the long run, those who spend their lives in the arts and wish to communicate the worth of these activities to those who do not (i.e., policy-makers, administrators, or any others who attempt to understand the value of the arts without the benefit of having experienced them). An inquiry-based approach to arts education means that all questions are on the table. The very things we take as 'givens,' our most fundamental assumptions, in the making of art and the teaching about it, are open to scrutiny. Such a stance would more explicitly support the work of critical arts researchers and practitioners. These are the arts and cultural workers in our arts communities who resist dominant discourses in arts agendas, like the current neo-liberal discourses of the 'creative class,' as one example. This would also leave room for arts pedagogies that challenge the notion of arts students as consumers of cultural commodities. Without this, our advocacy efforts are doomed to replicate the same stories about the arts, with claims that are near impossible to 'prove.' Advocacy is important, to be sure, but it must also be unleashed from research projects so that our research findings and our advocacy efforts can each become available to new conceptions and innovative platforms. 
Unrest in the domain of assessment or evaluation of creativity is a clear sign of the puzzlement most researchers and practitioners feel about what to count as creative and how to account for it. There is, at least in drama education where I spend most of my time, a further conceptual dilemma related to the kind of research on 'creativity' that occurs and its relatively poor currency in larger public arenas. While some large-scale arts studies have included measures for drama and produced some interesting findings, those "inside" the field of drama itself, have paid scant attention to its relationship to questions of creativity more generally. ${ }^{4}$ These are large questions and unwieldy that demand sophisticated methodological intervention.

The UNESCO Road Map also helps us see how the age-old debate about extrinsic versus intrinsic value in arts education thwarts progress in the area of research and assessment. There are, however, understandable reasons for these challenges and detours. In the case of drama, for instance, as a field it has had a rather ambivalent relationship to developmental psychology precisely because it desires to be valued for its intrinsic and cultural validity and not only for its instrumentality. In drama, children are both the creators and the created. Pragmatically speaking, then, it is very difficult to evaluate/measure/judge/research creativity when the unit of measurement is the children, not a painting, a composition, or a performance. And I mean here the study of children caught up in their engagement with the arts, not measured according to an accepted set of developmental claims. Furthermore, creativity in the drama classroom arises from complex social processes rather than moments of individual genius. These complex social processes make research (which question to ask, of whom, when and where) a much more complex undertaking. I know much less about the other arts disciplines, but I do know that a resistance to developmentalist formulations has a long and important history in all of them. Our official documents, such as the UNESCO Road Map, should also pay attention to these alternative voices because they often articulate the significant forms of arts engagement that cannot be captured by stages, ages, and other theories of development.

With a tenuous road map at best, in the world of sustained improvisation or process drama, ${ }^{5}$ creativity is experienced in the moment; it is seldom entirely pre-determined. In short, many in the field might agree that we engage dramatically through our imagination; an accurate measure of the imagination, however, is beyond our reach. Drama experiences may also vary considerably from child to child and may occur in the unanticipated moments of a given lesson. Furthermore, student engagement in whole group drama activities is both a collective and a deeply individual experience. The measure of this kind of layered engagement, then, becomes a very imprecise art form itself.

As a drama researcher, I have ultimately come to understand that there will always be trouble in the quest to evaluate how creativity manifests itself in drama classrooms and how we might best study it and then translate if for wider publics. The process/ product or script/improvisation debates are not simply a question of preference or habit. What we value in our pedagogy, the premium placed on skill acquisition or spontaneity continues to deeply divide the work. In both frameworks, however, the building of collective narratives is a complex undertaking in drama classrooms, as evidenced in both the practices we engage in and the eclectic fruits of our labour. 


\section{A Road Map Revisited}

As it nears its conclusion, the UNESCO Road Map calls for a research "Clearinghouse" or "Observatory (p. 13) and in my view such a clearinghouse should be multi-lingual. With translation software, this could be relatively easily accomplished. The idea of a Clearinghouse is a superb one and could go a long way towards democratizing knowledge about the arts, making it accessible for multiple audiences, including researchers disparately situated. But what this also points to is the need for more attention to be paid to the dangers of homogenizing cultural differences in arts practices and discourses. Our efforts to 'speak a common language' or standardize how it is we communicate with one another must also defend against a propensity to conflate or settle differences be they cultural, artistic, or political. At present, a fairly Eurocentric perspective reigns, but such a document would be well served by also openly signaling the tensions between cultural givens, the contested definitions of creativity, and the multiplicity of practices around the globe.

A road map is an excellent place to begin. It tells us the world is ultimately a coherent place, destinations are accessible, but, there are rivers to cross, bridges to build, boundaries to understand; there will be unanticipated journeys and that is a good thing. Let us continue to pay attention to the unanticipated, the unexpected and improvised of arts experiences that cannot so easily be calibrated and measured, alongside what is arguably an evolving and profoundly diverse and interesting understanding of research in arts education. It is easy to make claims in arts education but in tying arts practices too closely to outcomes or behaviours, be they 'emotional intelligence,' or 'creative, adaptable thinking,' we may also lose our capacity to critically challenge prevailing discourses or, even worse, foreclose our capacity to innovate. The claims are tempting, though, because the arts are most often in a position of defense, which makes it easy to fall into the trap of overstating them. As ever, the question is: who is our audience? Who are we trying to teach or persuade? Whose interests are we privileging? And the answers will vary wildly across arts communities. We need a road map that acknowledges our different audiences and political commitments.

In arts research, the qualitative researcher is asked to 'go visiting,' to consider events from unfamiliar standpoints. Hannah Arendt (1982) coined this useful concept of "visiting," and with its drive towards "imaginative judgment," she suggests that such visiting should distance us from the familiar and bring us to new standpoints that are unfamiliar. Here I find myself once again at the unexpected, or the unanticipated in arts research. In this, I find a key to deeper and more theoretical understandings of the stories we generate and rely so heavily upon in arts research. Standing back from the obvious, we might see whether new categories of analysis become possible. And then, we arrive somewhere else. Unknown at the outset perhaps, unanticipated even, but well worth the trouble. I am grateful for the dialogue that the UNESCO Road Map must now generate and look forward to where practitioners, artists, and researchers will take it. 


\section{Notes}

1. For a developed argument of this premise, please see Gallagher, K., Freeman, B., $\&$ Wessels, A. (2009). 'It could have been so much better': the aesthetic and social work of theatre. Research in Drama Education: The Journal of Applied Theatre and Performance, 15(1), 5-27.

2. I was listening to Linda Nathan from the Boston Arts Academy a few months ago at the Ontario Institute for Studies in Education. Our Centre for Urban Schooling had invited her to come and talk about her work in the arts as a principal of high school students in Boston. One of the things she said was that 'art was an entry point to life.' I liked it. But it also made me think about the point of the research I do. Hence, the concept: Art as an entry point to a life examined. Thank you Linda Nathan.

3. For an expansion of these ideas, please see the following chapter: Gallagher, K. (2008). The art of methodology. The methodological dilemma: Creative, collaborative and critical approaches to qualitative research. K. Gallagher (Ed.). pp. 67-81. London and New York: Routledge.

4. For a deeper analysis of this phenomenon in the field of drama education, please see Gallagher, K. (2007). Conceptions of creativity in drama education. In International handbook of research in arts education. pp. 1229-1240. L. Bresler (Ed.). New York, NY: Springer Publishing.

5. "Process drama" is a general term used to describe a method of drama instruction in which, typically, the teacher and the whole class enter into an imaginary context, often based on source material gathered by the teacher or students. The goal is to investigate any of a number of possible themes through sustained improvisation, during which students and teacher might take on a variety of roles and relationships through various theatrical conventions.

\section{References}

Arendt, H. (1982). Lectures on Kant's political philosophy. R. Beiner (Ed.). Chicago, IL: University of Chicago Press.

Friel, B. (1999). Brian Friel: Essays, diaries, interviews: 1964-1999. C. Murray (Ed.). New York, NY: Faber \&Faber.

Gallagher, K. (2007). The theatre of urban: Youth and schooling in dangerous times. Toronto, London, Buffalo: University of Toronto Press.

Gallagher, K. (2007). Conceptions of creativity in drama education. In International handbook of research in arts education. pp. 1229-1240. L. Bresler (Ed.). New York, NY: Springer Publishing.

Gallagher, K. (Ed.). (2008). The methodological dilemma: Creative, critical and collaborative approaches to qualitative research. New York and London: RoutledgeFalmer.

Gallagher, K., Freeman, B., \& Wessels, A. (2010). 'It could have been so much better': the aesthetic and social work of theatre. Research in Drama Education: The Journal of Applied Theatre and Performance, 15(1), 5-27.

Lerman, L. \& Borstel, J. (2003). Critical response process. Takoma Park, MD: Liz Lerman Dance Exchange.

Ng, R. \& Mirchandani, K. (2008). Linking global trends and local lives: Mapping the methodological dilemmas. In K. Gallagher (Ed.). The methodological dilemma: Creative, critical, and collaborative approaches to qualitative research. pp. 34-45. London: Routledge. 